\title{
WINNERS OF DISTINGUISHED ACHIEVEMENT AWARD OF WORLD POLITICAL ECONOMY OF THE 21st CENTURY (2013)
}

No. 2013001

Date: May 2013

Global Imbalances and the Global Crisis: A Preliminary Discussion

Ms. Jennifer Rebecca Clegg

No. 2013002

Date: May 2013

Comprehensive Advantages of Large Country

Mr. Yao Ouyang

No. 2013003

Date: May 2013

On the So-Called "Middle-Class Citizens" as the Power of Social Change Mr. Hiroshi Setooka

No. 2013004

Date: May 2013

Necessity of a Socialist Market Economy as a Stage in Transition From

Capitalism to a Socialist/Communist Society on the State Capitalism and "China Model"

Mr. Erwin Marquit

No. 2013005

Date: May 2013

Measurement, Enrichment and Development on Marx's Theory of Economic Crisis From the International Financial Crisis in Early 21st Century

Mr. Mingsheng Zhou

No. 2013006

Date: May 2013

Overexploitation Workforce and Concentration of Wealth: Key Issues for Development Policy in the Brazilian Peripheral Capitalism

Mr. Niemeyer Almeida Filho 
No. 2013007

Date: May 2013

The Latest Development of Development Economics: Development Economics with Chinese Characteristics

Mr. Xinhua Jian

No. 2013008

Date: May 2013

The Views of Some Economic Theories on the Economic Crisis of Capitalism and Some Lessons for Vietnam

Mr. Pham Van Duc

No. 2013009 (Cancelled)

No. 2013010

Date: May 2013

Reading Contemporary Capitalism: Essays on the 21st Century Society

Mr. Jean-Claude Delaunay 